\title{
Leave no one Behind. Design Inclusive Motor Activities in Primary Teacher Education Courses
}

\section{Antonello Mura, Ilaria Tatulli, Antioco Luigi Zurru}

Department of Pedagogy, Philosophy, Psychology, University of Cagliari, Italy.

\begin{abstract}
The development of international policies supporting inclusive education of people with disabilities has initiated a process of social democratization that requires specific interventions and skills of multiple professionals.

The education of future preschool and primary school teachers faces the challenge of inclusion and becomes fertile soil for the promotion of cultural change in society.

In this sense, starting from the experiences of planning and developing of inclusive motor activities, conducted for three years in the degree course in Primary Education Sciences of an Italian university, this research work collects testimonies, experiences and reflections of the students concerning both the learning gained in the workshops organized by the degree course and those acquired during the observation of the different public schools where they carried out the compulsory training to become teachers.

The results, collected by the qualitative analysis of data, induce different levels of reflection concerning the current schooling educational practices for teaching motor activity, the training needs of future teachers, the elaboration of specific contents and teaching methods/strategies for the preparation of spaces and tools that guarantee the full accessibility of learning for all the students.
\end{abstract}

Keywords: Inclusive Education; Motor Activity; Teachers’ Education. 


\section{Introduction}

The process of school inclusion started in Italy forty years ago since the promulgation of Law 517 in 1977, assuring the access to schooling for disabled pupils in mainstream schools. This innovative reform has produced several changes within the organization of educational institutions, it has enhanced relationships between school, territory and families, and also has improved teachers's professional and educational training, moreover has promoted emancipation opportunities for students with disabilities, these aspects have produced important changes for social integration (de Anna, 2014; Mura, 2016; Pavone, 2015).

"Leave no one behind", could be considered as a clear exhortation to the international community for the rights to a respectable and prosperous life. A recommendation that becomes a call to guarantee to all the students, since the early years of schooling, participation in inclusive educational pathways. These warnings are also present in numerous international documents as UNESCO, International Charter for Physical Education, Physical Activity and Sport 1978, World Conference on EFA, Jomtien, 1990, World Conference of Salamanca 1994 and UN Convention 2006. In particular, Article 30, advocates: "Participation in cultural life, recreation, leisure and sport: 1. States Parties recognize the right of persons with disabilities to take part on an equal basis with others in cultural life [...]”. These contents are riaffirmed in the 2012 in Indicazioni Nazionali per il Curriculum and in Rules for the promotion of school inclusion for disabled student in n. 66, 2017 Legislative Decree, they are also recalled and renewed in the Indicazioni e Nuovi Scenari, 2018. This principles have become an integral part of the learnings provided in the training course for Italian teachers.

In acceptance of these international and national indications it becomes fundamental to train the students of the course of Primary Education Sciences to a habitus of pedagogical and didactic skills that is able to recognize the whole person, the pupils with their needs, to develop every potentiality (de Anna, Gaspari, \& Mura, 2015; Mura \& Zurru, 2016).

\section{Lessons, workshops and training: an opportunity to learn about the inclusive potential of Motor Sciences}

In the lectures of the last three years, undergraduate students were guided into a path of knowledge of the different potentialities of Motor Sciences. This discipline is a complex domain, an interdisciplinary field of study, characterized by the interaction of the essential contributions of biomedical and humanistic studies (Seclì, 2014; Zedda, 2016). As a core subject in the graduation programme, these contents of knowledge contribute to the understanding of human development and education, becoming preparatory for didactic design. During the lessons are offered information about the motor and postural 
development stages of children, the learning and developmental meaning of the game, of the expressive, communicative and relational component as fundamental elements that contribute to the process of growth and awareness of each pupil's body and identity. Movement and game-sports activities are factors that support the interpretation of reality, that guide in the development of knowledge related to health education, and also in civil coexistence and responsible citizenship (MIUR, 2012). All the suggested themes are fundamental elements for the planning and evaluation of motor activities in an inclusive perspective, both for preschool and primary school.

However, it has been explained to students that the involvement in the motor activities of pupils with disabilities it is often hindered by different types of barriers. As pointed out two by researchers (Kasser \& Lytle, 2005) the greatest difficulties in inclusive motor activities are identified in three macro elements as personal and contextual factors, and factors related to the task. In this sense and from a perspective of integrated physical activity (Mura, 2011; de Anna, 2009, 2018), it becomes important to intervene with the search for adequate didactics solutions (Mura, 2009). The quality of inclusion is closely related to the teaching competencies, it implies the introduction of elements of innovation that correspond to each one's learning possibilities, independently of their disability condition (Moliterni, 2009, 2013; Mura, 2016; Pavone, 2015). For this reason it was considered appropriate to direct students to develop a systemic operational approach to change perspective and to recognize motor activities' qualities, the body and direct experiences as active, warm mediators that promote everyone's participation (Moliterni, 2013). The students have been solicited to the meta-reflection on the themes of integration and inclusion in motor activities with the knowledge of various experiences successfully carried out in different schools (Magnanini, 2009; Rossi, 2009). This educational path produced two different types of works. In the workshops students worked in small groups to design inclusive motor activities to share with all colleagues. The other works are the result of an oriented and improved reflection by individual students, who have perfected their reflection on inclusion with the planning of inclusive motor activities that have been realized during the direct training, those data became research material for the thesis.

\subsection{Students face the challenge of inclusion}

In 3 years, the workshop activities involved about 40 university students divided into 7 groups. Each year, at the end of the course, were collected the testimonies of students involved in the workshops, with interviews that highlighted important didactic elements for inclusion:

- basics motor skills are universal principles for the development of all pupils, regardless of whether they show special educational needs; 
- basic motor skills are preparatory and transversal to learnings in different disciplinary areas;

- it is necessary to check the conditions of physical and cognitive accessibility of learnings to promote participation of all the students;

- $\quad$ it is also relevant to know the formative value of motor and expressive activities for the creation of a positive communication and relationship between pupils.

From the perspective of professional growth, the students reported that workshops are useful to experiment, in a protected context, how to elaborate and check the project, to learn how to recognize and overcome obstacles to inclusion. Moreover they stated that is important to consider design workshops as an opportunity for share and integrate the different skills gained by colleagues.

Concerning the activities designed and implemented by individual students during the training in preschools and primary schools, they have become an open and complex challenge. In this research were involved 20 female students in training, who have designed inclusive motor activities and they were invited to describe the critical elements encountered in experimentation at school. The collected data describe different aspects, in fact, if on one hand students in training stated that it was necessary evaluate carefully school settings, because sometimes there are architectural barriers to enjoy gym or school's gardens, some other stated about difficulty in managing the time, in fact training time available wasn't enough to carry out all the designed activities. The interviews report that it was therefore necessary evaluate carefully all kind of tools and contents to ensure access and participation to all pupils. In this sense the students in training have highlighted how much time and energy they have committed to find suitable solutions. On the other hand, some students in training stated that it was difficult to share the objectives of the project with school's teachers, so it was necessary creating a climate of mediation, because not all of them show that they have gained knowledge about inclusive motor activities. However, pupils involved in these experiences have shown interest in the activities proposed and for the issues of inclusion. Children have enjoyed a new way of doing motor activity together, because they have been involved in a new cultural model that makes all the students protagonists respecting and recognizing the peculiarities of each one. Engaged in the process of designing and evaluating activities, students in training have reported that they have received multiple input to accomplish the operational evolution from theory to practice in inclusive motor activities design.

\section{Motor Activities and inclusive culture}

It has become clear that, participation in motor activities and sport is another opportunity to grow together, to learn with peers, to know themselves and each others, to be aware about 
each one's body, about own limits and strengths, and is also, above all, is the exercise of a right (de Anna \& Covelli, 2016; Mura, 2009; UN, 2006). Nevertheless school experiences described in some students' in training interviews show critical elements referred to architectural barriers and, more relevant, teachers' bias about inclusion in motor activities. The limits to participation, caused by architectural barriers and the absence of adequate tools, are notice of a cultural and institutional inclusion limit that still must be demolished. Certainly, those barriers are related to the absence of a real involvement in motor activities for students with disability. The interviews highlighted this lack of opportunities despite the latest Indicazioni e Nuovi Scenari (MIUR, 2018) and also the UN Convention (UN, 2006). By their point of view, students in traninig stated that on one hand some teachers would like to intervene with a medical approach, with the planning of specific motor activities for unique and specific need of each pupil with disability.

The disability of our student is too serious, he would need another type of intervention, in other spaces. It's too serious, don't worry about him, work with others (a primary school teacher).

On the other hand they do not have adequate methodologies to involve pupils with disabilities and so they prefer a policy of non-intervention.

Organizing activities with them is too complicated. It implies to leave the classroom, moreover, you know, they are two pupils with disability ... (a preschool teacher).

Moreover, in three cases, students in training said they had tried several times to share their projects of inclusive motor activities with some teachers, but they do not received a real interest or appreciation towards the proposed work.

I tried for many times to share with them the project, but they told me that I was free to do what I want (an undergraduate student).

Gathering those testimonies and reflections, becomes important to understand the nature of these prejudices, and try to propose possible solutions to fill a gap that could undermine the emancipation objectives achieved in these years.

The fragility of these teaching experiences requires a greater investment of energies and resources. Some studies suggest that it is necessary to invest in training towards inclusive approaches for all teachers, for all disciplines (de Anna \& Covelli, 2016; Mura \& Zurru, 2019; Zurru, 2015). More precisely and in order to become professionals in the discipline, it is urgent that all the teachers involved in the motor area would be trained both in basic pedagogical skills and in specific skills regarding the body pedagogy (Milani \& Crotti, 2016). Greater investment in the dissemination of inclusive practices, also through the motor sciences, can become an opportunity to improve not only individual's skills, but to enhance learning conditions of all pupils. The experiences of motor inclusion proposed 
during the lessons and the projects developed by the students in training are potential levers for teaching practices and cultural change. In this sense, it is important to invest both in the training of future teachers and in the updating of teachers in service.

Fostering of an inclusive and integrated education approach, that receives the educational needs of each pupil, requires a continuous effort in pedagogical research of models, strategies and instruments, in a lifelong learning perspective of innovative didactic and educational practices (d’Alonzo, Bocci, \& Pinnelli, 2015; Zurru, 2015).

In this educational pathway, which involved university students both in the training through the lessons, the workshops and the traineeships, and it has been realized in three years emerge some useful elements: it's clear that lessons and workshops are opportunities to confront a new operational reality that allows to change own's perspectives respect to the different potentialities of the motor sciences. Moreover Primary Education Science training can become an instrument for the change of the design culture and it can become a quality resource for didactics and teaching. Remodelling their point of view, university students during their training in schools are active guests and promoters of change. They are "spores" for the dissemination of the design of inclusive motor activities, they involve teachers and pupils in theoretical reflection, they seek solutions and answers to unrecognized educational needs, moreover, they collect the children's questions as exhortations to deepen the themes of scholastic and social inclusion.

\section{References}

d’Alonzo, L., Bocci, F., \& Pinnelli, S. (Eds.). (2015). Didattica speciale per l'inclusione. Brescia: La Scuola.

de Anna, L., \& Covelli, A. (2016). Attività motorie e sportive inclusive. In M. Morandi (Eds.), Corpo, educazione fisica, sport. Questioni pedagogiche. (pp. 130-147). Milano: FrancoAngeli.

de Anna, L. (2014). Pedagogia Speciale. Integrazione e inclusione. Roma: Carocci.

de Anna, L., Gaspari, P., \& Mura, A. (Eds.). (2015). L'insegnante specializzato. Itinerari di formazione per la professione. Milano: FrancoAngeli.

Kasser, S.L., \& Lytle, R.K. (Eds.). (2005). Inclusive physical activity. A Lifetime of Opportunities. Champaign: Human Kinetics.

Magnanini, A. (2009). Lo Sport... per tutti. Una risorsa per l'integrazione. In L. de Anna (Ed.), Processi formativi e percorsi di integrazione nelle scienze motorie. Ricerca, teorie e prassi (pp. 188-195). Milano: FrancoAngeli.

Milani, L., \& Crotti, M. (2016). Due professionalità: insegnanti e allenatori. In M. Morandi (Eds.), Corpo, educazione fisica, sport. Questioni pedagogiche. (pp. 111-128). Milano: FrancoAngeli.

MIUR. (2012). Indicazioni nazionali per il curricolo della scuola dell'infanzia e del primo ciclo di istruzione. In Annali della Pubblica Istruzione. 
MIUR. Indicazioni Nazionali e nuovi scenari (2018). Roma.

Moliterni, P. (2009). La mediazione didattica e le attività motorie per l'integrazione. In L. de Anna (Ed.), Processi formativi e percorsi di integrazione nelle scienze motorie. Ricerca, teorie e prassi (pp. 317-329). Milano: FrancoAngeli.

Moliterni, P. (2013). Didattica e scienze motorie. Tra mediatori e integrazione. Roma: Armando.

Mura, A. (2009). Pregiudizi e sfide dell'inclusione: le attività motorie e sportive integrate. In L. de Anna (Ed.), Processi formativi e percorsi di integrazione nelle scienze motorie. Ricerca, teorie e prassi (pp. 111-137). Milano: FrancoAngeli.

Mura, A. (2016). Diversità e inclusione. Prospettive di cittadinanza tra processi storicoculturali e questioni aperte. Milano: FrancoAngeli.

Mura, A., \& Zurru, A. L. (2016). Riqualificare i processi inclusivi: un'indagine sulla percezione degli insegnanti di sostegno in formazione. L'integrazione Scolastica $e$ Sociale, 15(2), 150-160.

Mura, A., \& Zurru, A. L. (2019). Professionalità docente e processi di inclusione: dall'indagine sulle pratiche didattiche alla rilevazione dei bisogni formativi. L'integrazione Scolastica e Sociale, 18(1), 48-62.

Pavone, M. (2015). Scuola e bisogni educativi speciali. Milano: Mondadori.

Rossi, C. (2009). La persona in situazione di disabilità grave a scuola: la relazione, il corpo, il movimento. In L. de Anna (Ed.), Processi formativi e percorsi di integrazione nelle scienze motorie. Ricerca, teorie e prassi (pp. 330-340). Milano: FrancoAngeli.

Seclì, P. (2014). Orizzonti di senso per l'Educazione Fisica. In A. Seclì, \& P. Ceciliani (Eds.), Metodi e strumenti per l'insegnamento e l'apprendimento delle scienze motorie (pp. 1-54). Napoli: EdiSES.

UN (2006). Convenction on the Rights of Persons with Disabilities. New York: UN.

Zedda, M. (2016). L'educazione fisica: spunti epistemologici. In M. Morandi (Ed.), Corpo, educazione fisica, sport. Questioni pedagogiche (pp. 41-53). Milano: FrancoAngeli.

Zurru, A. L. (2015). Gli insegnanti e la ricerca: itinerari per l'inclusione. In L. de Anna, P. Gaspari, \& A. Mura (Eds.), L'insegnante specializzato. Itinerari di formazione per la professione (pp. 124-136). Milano: FrancoAngeli. 